\title{
Relationship Between the Thermodynamic Parameters, Structure, and Anticorrosion Properties of $\mathrm{Al}-\mathrm{Zr}-\mathrm{Ni}-\mathrm{Fe}-\mathrm{Y}$ Alloys
}

\author{
R. BABILAS, W. ŁOŃSKI, K. MŁYNAREK, A. BAJOREK, and A. RADOŃ
}

The influence of the chemical composition on the crystallization process, amorphous phase formation, and the anticorrosion properties of $\mathrm{Al}-\mathrm{Zr}-\mathrm{Ni}-\mathrm{Fe}-\mathrm{Y}$ alloys are presented. To reduce the number of experiments, a thermodynamic approach was applied in which the entropy and Gibbs free energy of representative alloys were optimized. The low glass-forming ability of $\mathrm{Al}-\mathrm{Zr}-\mathrm{Ni}-\mathrm{Fe}-\mathrm{Y}$ alloy systems was related to the crystallization of the $\mathrm{Al}_{3} \mathrm{Zr}$ phase from the melt. The structural analysis showed that phases containing $\mathrm{Ni}$ and $\mathrm{Fe}$, such as $\mathrm{Al}_{19} \mathrm{Ni}_{5} \mathrm{Y}_{3}, \mathrm{Al}_{10} \mathrm{Fe}_{2} \mathrm{Y}$, and $\mathrm{Al}_{23} \mathrm{Ni}_{6} \mathrm{Y}_{4}$, played a key role in the formation of amorphous alloys. According to this, the simultaneous addition of $\mathrm{Ni} / \mathrm{Fe}$ and $\mathrm{Y}$ is important to prevent the crystallization of Al-based alloys in the melt. The formation of an amorphous phase in $\mathrm{Al}_{80} \mathrm{Zr}_{5} \mathrm{Ni}_{5} \mathrm{Fe}_{5} \mathrm{Y}_{5}$ alloys and the complete amorphization of $\mathrm{Al}_{85} \mathrm{Ni}_{5} \mathrm{Fe}_{5} \mathrm{Y}_{5}$ alloys were responsible for the high corrosion resistance compared with fully crystalline alloys. Moreover, the addition of $\mathrm{Y}$ had a significant impact on the anticorrosion properties. The XPS results showed that the alloys tended to form a passive $\mathrm{Al}_{2} \mathrm{O}_{3}$ and $\mathrm{Y}_{2} \mathrm{O}_{3}$ layer on the surface.

https://doi.org/10.1007/s11661-020-05833-x

(c) The Author(s) 2020

\section{INTRODUCTION}

LIGHTWEIGHT alloys are mainly applied in the aerospace industry where high strength and low density are required. The application of conventional aluminum alloys is limited due to their relatively low strength, which is insufficient for advanced structural applications. ${ }^{[1]}$. Particular attention has been paid to aluminum alloys whose structure and properties can be improved by rapid solidification (RS). Al matrix alloys produced by RS are characterized by their non-equilibrium phases: amorphous single phase, partially crystallized particles in an amorphous matrix, quasicrystalline structures consisting of quasicrystals in an $\mathrm{Al}$ matrix without a grain boundary, and granular amorphous phases of aluminum with or without a surrounding amorphous phase. ${ }^{[1,2]}$ Bulk metallic glasses (BMGs) are an interesting group of materials produced by RS, and Al-based BMGs (Al-BMGs) are a promising group of

R. BABILAS, W. LOŃSKI, and K. MŁYNAREK are with the Department of Engineering Materials and Biomaterials, Silesian University of Technology, Konarskiego 18a St., 44-100 Gliwice, Poland. Contact e-mail: Rafal.babilas@polsl.pl A. BAJOREK is with the Institute of Physics, University of Silesia in Katowice, 75 Pułku Piechoty 1, 41-500 Chorzów, Poland. A. RADON is with the Lukasiewicz Research Network - Institute of Non-Ferrous Metals, Sowińskiego 5 St., 44-100 Gliwice, Poland

Manuscript submitted November 26, 2019.

Article published online May 25, 2020 engineering materials that have good mechanical properties with a combination of a high strength and a low density. ${ }^{[3]}$ BMG production techniques include melt-spinning, water quenching, copper mold casting, and arc melting. ${ }^{[4]}$ High-pressure casting also produces an amorphous surface layer on aluminum alloys. ${ }^{[1]}$ The formation of an amorphous phase requires that materials have a glass-forming ability (GFA), which states that alloys should contain more than three elements with $>12$ pct atomic size differences and negative mixing enthalpy. ${ }^{[5]}$ These empirical rules for conventional BMG alloys are different for most amorphous Al-based alloys. $^{[6,7]}$ In many cases, Al-BMGs require a higher critical cooling rate $\left(10^{5}-10^{6} \mathrm{~K} / \mathrm{s}\right)$ than typical bulk metallic glasses. Poon et al. ${ }^{[8]}$ indicated that a high GFA in aluminum alloys can be achieved by slowing the atomic diffusion, optimizing the entropy between a supercooled liquid and crystal, as well as a low liquidus temperature to reduce the cooling rate before vitrification occurs. The GFA of several amorphous Al-BMGs has been verified in many systems prepared by melt-spinning, including $\mathrm{Al}-\mathrm{Y}-\mathrm{Fe},{ }^{[9]} \mathrm{Al}-\mathrm{Ni}-\mathrm{Zr},{ }^{[10]}$ Al-Fe-Zr ${ }^{[10]}$ Al-Fe-Y, ${ }^{[11,12]}$ Al-Y-Ni, ${ }^{[13]}$ Al-Ni-Fe, ${ }^{[14]}$ Al-Ni-Y, ${ }^{[3,15]}$ Al-Ni-Fe-Gd, ${ }^{[16]}$ and Al-Ni-Y-Co-Fe. ${ }^{[17]}$ The composition of an Al-La-Fe-Ni alloy produced by spark plasma sintering exhibited a partly amorphous structure (i.e., $\left.\mathrm{Al}_{88}-\mathrm{La}_{6}-\mathrm{Fe}_{3}-\mathrm{Ni}_{3}\right) .{ }^{[18]}$ Quasicrystals with a volume fraction of 30 pct were identified in $\mathrm{Al}_{85} \mathrm{Ni}_{5} \mathrm{Y}_{6}$ $\mathrm{Co}_{2} \mathrm{Fe}_{2}$ produced by gas atomization. ${ }^{[17]}$ 
In order to obtain nanocrystalline structures and high-quality alloys with aluminum matrixes, the chemical composition, atomic diameters, atomic pair interactions, and liquid temperature must be carefully considered. ${ }^{[8]}$ Aluminum alloys containing rare earths (RE) and transition metals (TM) are characterized by high mechanical strength and wear and corrosion resistance. ${ }^{[19]}$ The combination of $\mathrm{Al}-\mathrm{Zr}-\mathrm{Ni}-\mathrm{Fe}-\mathrm{Y}$ gives rise to properties demanded in structural metals due to the addition of alloying elements which influences the structural and mechanical properties. ${ }^{[20]} \mathrm{Al}+\mathrm{TM}+\mathrm{RE}$ systems containing partially crystallized phases in an amorphous matrix were used to form a nanocomposite with outstanding mechanical properties. ${ }^{[19]}$ Zirconium addition to $\mathrm{Al}-\mathrm{Zn}-\mathrm{Mg}$ alloys resulted in the formation of a coherent $\mathrm{Al}_{3} \mathrm{Zr}$ phase whose precipitation was responsible for improving the mechanical properties and corrosion resistance, as well as grain refinement and resistance to recrystallization. ${ }^{[21]}$ The addition of nickel improved the hardness, compression, and flexural resistance due to the distribution of intermetallic $\mathrm{Al}_{3} \mathrm{Ni}$ in the Al matrix. ${ }^{[20]}$ The addition of iron can increase the strength of an alloy. Sasaki et al. ${ }^{[22]}$ indicated that a nanocrystalline $\mathrm{Al}_{6} \mathrm{Fe}$ phase formed in bulk Al-Fe alloy samples formed by spark plasma sintering. Furthermore, literature data describe the beneficial effects of rare-earth elements like yttrium on the mechanical properties. ${ }^{[20]}$ Al-based alloys with optimized chemical compositions have shown high strength, low density, good ductility, and high corrosion resistance. ${ }^{[16,23]}$ Al-based BMGs have demonstrated tensile strengths above $1000 \mathrm{MPa}$, which is two times higher than conventional aluminum-based alloys. ${ }^{[6]}$ Moreover, the mechanical properties of many Al-BMGs can be improved by forming composite materials containing crystalline fcc $\mathrm{Al}$ particles in an amorphous matrix. ${ }^{[18]}$

The aim of this work was to identify the structure of Al-Zr-Ni-Fe-Y alloys whose compositions were experimentally determined using thermodynamics calculations. The predicted compositions necessary to obtain a glassy structure were determined using parameters connected to entropy and the Gibbs free energy of mixing. ${ }^{[24]}$ The use of a thermodynamics approach allowed the number of experiments to be reduced, the crystallization mechanism to be determined, and to describe the effect of all chemical elements on the formation of an amorphous phase. Structures were investigated using X-ray diffraction and light microscopy. Electrochemical corrosion resistance tests were also performed using the potentiodynamic method. Additionally, X-ray photoelectron spectroscopy (XPS) was used to investigate the passivation of alloys.

\section{MATERIALS AND METHODS}

\section{A. Thermodynamic Calculations}

In these studies, the chemical composition of Al-Zr$\mathrm{Ni}-\mathrm{Fe}-\mathrm{Y}$ alloys was determined based on the optimization of entropic thermodynamic parameters associated with entropy. For this purpose, the configuration entropy $\left(\Delta S^{\text {config }}\right)$, mismatch entropy $\left(\Delta S^{\text {mis }}\right)$, and the sum of these entropies $\left(\Delta S^{\text {sum }}\right)$ were calculated according to Eqs. (1)-(8). Moreover, the mixing contribution was taken into account by calculating the Gibbs free energy of mixing according to Eqs. (9)-(11). The maximization of entropy should lead to obtaining alloys with unique structures and properties.

The configurational entropy was determined based on Boltzmann's hypothesis concerning the relationship between entropy and chemical composition ${ }^{[25-28]}$ :

$$
\Delta S^{\text {config }}=-R \sum_{i=1}^{n} c_{i} \ln c_{i}
$$

where $R$ is the gas constant and $c_{i}$ is the concentration of the $i$-th chemical element.

The second parameter, mismatch entropy, was calculated according to the equations used by Takeuchi and Inoue, using the gas constant instead of Boltzmann's constant $^{[29]}$ :

$$
\begin{gathered}
\Delta S^{\text {mis }}=R\left[\frac{3}{2}\left(\zeta^{2}-1\right) y_{1}+\frac{3}{2}(\zeta-1)^{2} y_{2}\right. \\
\left.-\left\{\frac{1}{2}(\zeta-1)(\zeta-3)+\ln \zeta\right\}\left(1-y_{3}\right)\right] \\
\zeta=\frac{1}{1-\xi} \\
y_{1}=\frac{1}{\sigma^{3}} \sum_{j>1=1}^{3}\left(d_{i}+d_{j}\right)\left(d_{i}-d_{j}\right)^{2} c_{i} c_{j} \\
y_{2}=\frac{\sigma^{2}}{\left(\sigma^{3}\right)^{2}} \sum_{j>1=1}^{3} d_{i} d_{j}\left(d_{i}-d_{j}\right)^{2} c_{i} c_{j} \\
\sigma^{k}=\sum_{i=1}^{3} c_{i} d_{i}^{k} ; k=2,3 \\
y_{3}=\frac{\left(\sigma^{2}\right)^{3}}{\left(\sigma^{3}\right)^{2}}
\end{gathered}
$$

where $\xi$ is the packing fraction $(0.64$ for dense random packing) and $d_{i}$ and $d_{j}$ are the atomic diameters of chemical elements $i$ and $j$.

The sum of both, the configurational and mismatch entropy, was expressed as follows:

$$
\Delta S^{\text {sum }}=\Delta S^{\text {config }}+\Delta S^{\text {mis }}
$$

The Gibbs free energy of mixing (Eq. 9, 10, and 11) was determined based on the calculated entropies and chemical enthalpy of mixing $\left(\Delta H^{\mathrm{mix}}\right)$ of amorphous alloys calculated from Miedema's model using the Miedema Calculator for enthalpy of amorphous alloys ${ }^{[30-33]}$ : 


$$
\begin{gathered}
\Delta G^{\mathrm{mix}, \mathrm{conf}}=\Delta H^{\mathrm{mix}}-T \Delta S^{\mathrm{config}} \\
\Delta G^{\mathrm{mix}, \mathrm{mis}}=\Delta H^{\mathrm{mix}}-T \Delta S^{\mathrm{mis}} \\
\Delta G^{\mathrm{mix}, \mathrm{sum}}=\Delta H^{\mathrm{mix}}-T \Delta S^{\mathrm{sum}}
\end{gathered}
$$

where $T$ is the average melting temperature calculated according to equation (12):

$$
T=\sum_{i=1}^{n} c_{i} T_{m, i}
$$

where $T_{m, i}$ is the melting temperature of pure element $i$.

The optimization process was carried out in Microsoft Office Excel Solver tool using the Evolutionary Solving Method for non-smooth optimization problems. The alloy composition was varied until the optimum was reached. Since objective functions were used (Eqs. [1], [2], [8], [9], [10], and [11]), the function variables were the atomic concentration of elements, with some restrictions: (a) at. pet of $\mathrm{Al} \geq 80$ and $\leq 100$, (b) at. pct of $\mathrm{Zr}$, $\mathrm{Ni}$, and $\mathrm{Fe}, \mathrm{Y} \leq 10$ and $\geq 0$. The algorithm parameters are listed in Table I.

The chemical composition of Al-Zr-Ni-Fe-Y alloys, along with their calculated thermodynamic parameters, are listed in Table II. The optimized parameters are in bold.

The calculations show that the chemical composition determined based on the minimization of $\Delta G^{\mathrm{mix} \text {, sum }}$ and $\Delta G^{\mathrm{mix}}$, mis was nearly the same. Therefore, five alloys were chosen for further analysis:

- $\mathrm{Al}_{80} \mathrm{Zr}_{5} \mathrm{Ni}_{5} \mathrm{Fe}_{5} \mathrm{Y}_{5}$, in which all alloying additives are at the same atomic concentration,

Table I. Evolutionary Algorithm Parameters Used to Optimize the Values of Thermodynamic Parameters

\begin{tabular}{lc}
\hline Parameter & Value \\
\hline Convergence & 0.0001 \\
Mutation Rate & 0.075 \\
Population Size & 1000 \\
Random Seed & 0 \\
Maximum Time Without Improvement [s] & 30 \\
\hline
\end{tabular}

- $\mathrm{Al}_{80} \mathrm{Zr}_{0} \mathrm{Ni}_{0} \mathrm{Fe}_{10} \mathrm{Y}_{10}$, which contains only $\mathrm{Fe}$ and $\mathrm{Y}$ additives,

- $\mathrm{Al}_{80} \mathrm{Zr}_{4.7} \mathrm{Ni}_{4.39} \mathrm{Fe}_{4.27} \mathrm{Y}_{6.64}$, with a high configurational entropy; however, the atomic concentrations are not the same,

- $\mathrm{Al}_{80} \mathrm{Zr}_{9.97} \mathrm{Ni}_{2.15} \mathrm{Fe}_{0.06} \mathrm{Y}_{7.82}$, in which $\mathrm{Zr}$ and $\mathrm{Y}$ are favorable, but $\mathrm{Ni}$ is also present, and

- $\mathrm{Al}_{80} \mathrm{Zr}_{9.97} \mathrm{Ni}_{0.03} \mathrm{Fe}_{0} \mathrm{Y}_{10}$, in which $\mathrm{Zr}$ and $\mathrm{Y}$ are the main alloying additives.

These five alloys were used to investigate the influence of $\mathrm{Zr}, \mathrm{Ni}, \mathrm{Fe}$, and $\mathrm{Y}$ on the formation of an amorphous phase, as well as the crystallization of unconventional Al-based alloys.

\section{B. Experimental Methods}

The master alloys were prepared by the induction melting of $\mathrm{Al}, \mathrm{Zr}, \mathrm{Fe}, \mathrm{Ni}$, and $\mathrm{Y}$ (99.9 pct) under an argon atmosphere in a ceramic crucible. The ingots were melted to ensure homogeneity. Then, plates with a thickness of $1 \mathrm{~mm}$ were cast using a high-pressure die and ribbons melt-spinning method. ${ }^{[15]}$

The phase identification and structural verification of the samples were performed using X-ray diffraction (XRD). All samples were formed into a powder, and XRD patterns were recorded using a Rigaku Mini Flex 600 equipped with a copper tube as an X-ray radiation source and a D/TEX strip detector. Differential thermal analysis (DTA) was performed using a NETSCH Jupiter STA 449 F3 thermal analyzer. The DTA curves were recorded at a cooling rate of $20 \mathrm{~K} / \mathrm{min}$ under a protective argon atmosphere. The microstructure of the master alloys and plates was analyzed using a Zeiss Axio Observer light microscope. Weck's reagent was used as a color etchant to reveal the structure of alloys. For this purpose, $4 \mathrm{~g}$ of $\mathrm{KMnO}_{4}$ and $1 \mathrm{~g}$ of $\mathrm{NaOH}$ were dissolved in $100 \mathrm{~mL}$ of distilled water. The etching process was conducted at room temperature using an etching time from 30 to 40 seconds.

The surface structures of $\mathrm{Al}_{80} \mathrm{Zr}_{5} \mathrm{Ni}_{5} \mathrm{Fe}_{5} \mathrm{Y}_{5}, \mathrm{Al}_{80} \mathrm{Zr}_{0}$ $\mathrm{Ni}_{0} \mathrm{Fe}_{10} \mathrm{Y}_{10}$, and $\mathrm{Al}_{80} \mathrm{Zr}_{9.97} \mathrm{Ni}_{2.15} \mathrm{Fe}_{0.06} \mathrm{Y}_{7.82}$ ribbons were determined using $\mathrm{X}$-ray photoelectron spectroscopy (XPS) in the depth profile mode, using a Physical Electronics (PHI 5700/660) spectrometer working under an ultra-high vacuum $\left(10^{-9}\right.$ Torr), and a monochromatic Al $K \alpha$ X-ray source (1486.6 eV). XPS

Table II. The Chemical Compositions of Alloys Determined Based on the Maximization of Entropy and Minimization of the Gibbs Free Energy of Mixing

\begin{tabular}{lccccr}
\hline Chemical Composition & $\Delta S^{\text {config }}$ & $\Delta S^{\text {mis }}$ & $\Delta S^{\text {sum }}$ & $\Delta G^{\text {mix, conf }}$ & $\Delta G^{\text {mix, mis }}$ \\
\hline $\mathrm{Al}_{80} \mathrm{Zr}_{5} \mathrm{Ni}_{5} \mathrm{Fe}_{5} \mathrm{Y}_{5}$ & 6.47 & 1.01 & 7.48 & -33.16 & -27.05 \\
$\mathrm{Al}_{80} \mathrm{Zr}_{0} \mathrm{Ni}_{0} \mathrm{Fe}_{10} \mathrm{Y}_{10}$ & 5.31 & 1.45 & 6.76 & -27.68 & -23.41 \\
$\mathrm{Al}_{80} \mathrm{Zr}_{4.7} \mathrm{Ni}_{4.39} \mathrm{Fe}_{4.27} \mathrm{Y}_{6.64}$ & 6.44 & 1.13 & 7.57 & -33.78 & -27.84 \\
$\mathrm{Al}_{80} \mathrm{Zr}_{9.97} \mathrm{Ni}_{2.15} \mathrm{Fe}_{0.06} \mathrm{Y}_{7.82}$ & 5.78 & 1.03 & 6.81 & -38.50 & -29.29 \\
$\mathrm{Al}_{80} \mathrm{Zr}_{9.97} \mathrm{Ni}_{0.03} \mathrm{Fe}_{0} \mathrm{Y}_{10}$ & 5.33 & 1.11 & 6.44 & -38.29 & -35.04 \\
$\mathrm{Al}_{80} \mathrm{Zr}_{10} \mathrm{Ni}_{0} \mathrm{Fe}_{0} \mathrm{Y}_{10}$ & 5.42 & 1.13 & 6.55 & -38.62 & -33.48 \\
\hline
\end{tabular}


samples were held under vacuum $\left(10^{-9}\right.$ Torr $)$ for $12 \mathrm{~h}$, and survey spectra were measured with a pass energy of $187.85 \mathrm{eV}$. Depth profile (DP-XPS) analysis was carried out using a $1.5 \mathrm{kV} \mathrm{Ar}{ }^{+}$beam for 15 minutes, sputtering in intervals between measurements. The collected data was analyzed using MultiPak 9.2 software, which contains an internal reference database, and also compared to the NIST XPS database.

Electrochemical measurements were conducted in 3.5 pet $\mathrm{NaCl}$ solution using an Autolab $302 \mathrm{~N}$ potentiostat equipped with a three-electrode cell and controlled by NOVA software. A saturated calomel electrode (SCE) was used as the reference electrode and a platinum rod as the counter electrode. The corrosion resistance was evaluated by recording the open-circuit potential $\left(E_{\mathrm{OCP}}\right)$ variation versus SCE. Samples were measured after a period of open-circuit potential stabilization for 3600 seconds and a scan rate of $1 \mathrm{mV} \mathrm{s}^{-1}$. The corrosion potential $\left(E_{\text {corr }}\right)$, corrosion current density $\left(j_{\text {corr }}\right)$, and polarization resistance $\left(R_{\mathrm{p}}\right)$ were also determined according to the Stern-Geary method:

$$
j_{\text {corr }}=\frac{\beta_{a}\left|\beta_{c}\right|}{2.303\left(\beta_{a}+\left|\beta_{c}\right|\right)} \frac{1}{R_{p}}=\frac{B}{R_{p}},
$$

where $\beta_{a}$ is the anodic and $\beta_{c}$ is the cathodic Tafel slope calculated from Tafel extrapolation. ${ }^{[34]}$ The corrosion rate $\left(v_{\text {corr }}\right)$ based on the corrosion current density was also calculated. The surface morphology of samples in the as-plated state after polarization tests was observed by using a ZEISS SteREO Discovery V.12 light microscope.

\section{RESULTS AND DISCUSSION}

Figure 1 presents the XRD patterns of Al-based alloys in the as-cast state (a) and plate form (b). Table III summarizes the information of the phases identified in all alloys, which shows that upon increasing the $\mathrm{Zr}$ content, $\mathrm{Al}_{3} \mathrm{Zr}$ phase became the dominant phase in all alloys. Moreover, in alloys in plate form, new phases such as $\mathrm{Ni}_{3} \mathrm{Al}$ and $\mathrm{AlNi}_{2} \mathrm{Zr}$ were observed, which were associated with non-equilibrium crystallization under the higher cooling rate. After casting the alloys in plate form, all diffraction peaks broadened due to microstructure fragmentation. Moreover, the intensity of the $\mathrm{Al}_{3} \mathrm{Zr}$ peak in the alloys with a higher $\mathrm{Zr}$ content significantly decreased (especially the intensity of the diffraction peak at $20.5^{\circ}$ corresponding to the $\left(\begin{array}{lll}0 & 0 & 4\end{array}\right)$ lattice plane).

To confirm changes in the microstructure, optical microscopy images (Figure 2) of alloys were recorded after color etching, which reveals phases due to their different behavior when treated with Weck's reagent. This analysis showed that the light gray grains in the form of short plates were associated with the presence of the $\mathrm{Al}_{3} \mathrm{Y}$ phase, whereas the dark gray grains in the form of long, well-crystallized plates were $\mathrm{Al}_{3} \mathrm{Zr}$ phase. The brown grains were related to phases containing $\mathrm{Al}$ with $\mathrm{Fe}$ or/and $\mathrm{Ni}$ and the observed shades are related to the concentration of these elements in the phases. An

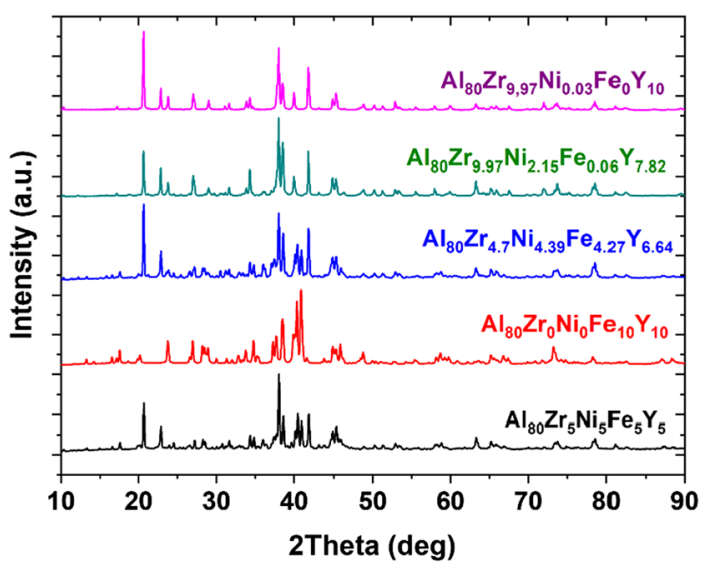

(a)

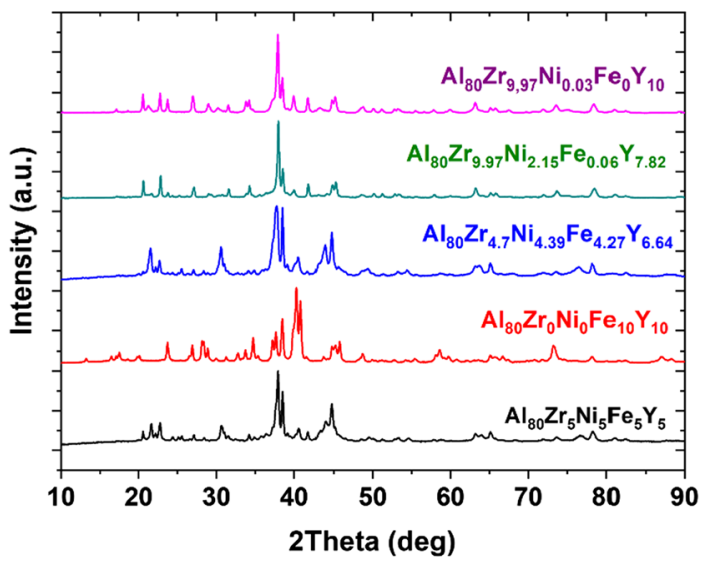

(b)

Fig. $1-$ XRD patterns of alloys in the as-cast state $(a)$ and in the form of plates $(b)$.

aluminum solid solution was observed between the intermetallic grains. The microscopy images of the cast plates confirmed the fragmentation of the structure. All phases existed in the form of needles between which existed aluminum.

To test the glass-forming ability of the prepared multiphase alloys, the alloys were remelted and cast in the form of ribbons by the melt-spinning method. Based on the XRD pattern analysis (Figure 3), the main crystalline phases in alloys cast in the form of ribbons were identified and are listed in Table IV. The optimization of both the configurational and mismatch entropy allowed alloys to be obtained in the shape of ribbons in which the main phase was an amorphous matrix that contained $\mathrm{Al}_{3} \mathrm{Zr}$ crystallites. No amorphous phase was detected in other alloys, but very broad diffraction peaks were observed in their XRD patterns. Thus, it can be concluded that a high entropy is responsible for the formation of a stable amorphous phase; however, the chemical composition is also an important parameter. As can be seen, the addition of zirconium resulted in the crystallization of the $\mathrm{Al}_{3} \mathrm{Zr}$ phase. Therefore, this phase negatively influences the formation of an amorphous phase in Al-based alloys. On the other hand, the addition of 10 at. pct Fe and Y did not lead to the formation of an amorphous phase; 


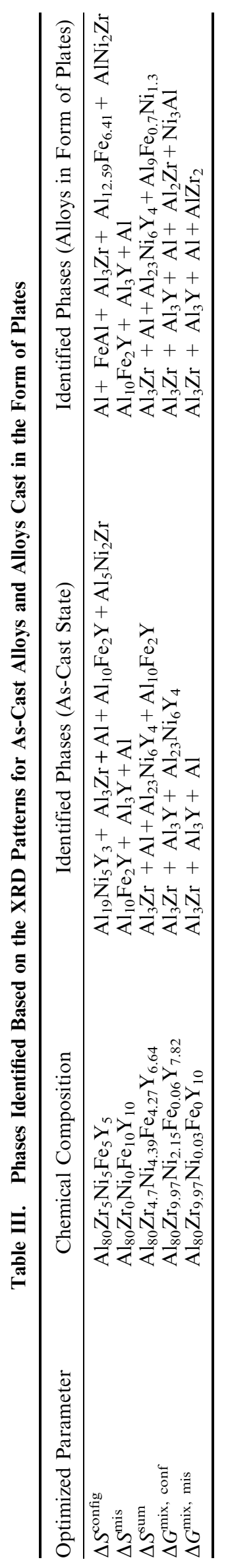

therefore, the addition of a third element, such as nickel, is also important to this process.

To understand this phenomenon, $\mathrm{Al}_{85} \mathrm{Ni}_{5} \mathrm{Fe}_{5} \mathrm{Y}_{5}$ was prepared. The XRD patterns of this alloy in the as-cast state and in the form of plates and ribbons are presented in Figure 4. Two main phases, $\mathrm{Al}$ and $\mathrm{Al}_{23} \mathrm{Ni}_{6} \mathrm{Y}_{4}$, were identified in the XRD patterns of the as-cast alloy and in the form of a plate, as well as a third phase, $\mathrm{Al}_{10} \mathrm{Fe}_{2} \mathrm{Y}$. Significant structure changes can be observed for this alloy when cast in the form of a plate. Al was still present, but diffraction peaks from other phases disappeared, which were associated with the formation of metastable phases. Moreover, the alloy prepared by melt-spinning displayed an amorphous structure with an asymmetric diffraction halo associated with short-range disorder corresponding to the (lllll 111$)$ and $\left(\begin{array}{lll}2 & 0 & 0\end{array}\right)$ lattice planes, respectively.

Finally, the crystallization mechanism of this new group of Al-Zr-Ni-Fe-Y alloys was proposed based on the DTA curves (Figure 5). Structural analysis was performed and is schematically presented in Figure 6. As previously stated, the low glass-forming ability of alloys containing $\mathrm{Zr}$ was due to the formation of the $\mathrm{Al}_{3} \mathrm{Zr}$ phase, which has a high melting temperature. Therefore, this is the first phase formed from the liquid state. Afterward, the $\mathrm{Al}_{3} \mathrm{Y}$ phase is formed between grains of this phase. The melting temperature of this phase is much lower than the $\mathrm{Al}_{3} \mathrm{Zr}$ phase; therefore, alloys containing yttrium are much more likely to undergo amorphization than those with zirconium. Moreover, the melting of this phase decreased strongly upon decreasing the Y content. After crystallization of these phases, the phases containing $\mathrm{Fe}$ and $\mathrm{Ni}$ crystallized in the grains. These phases have a much lower melting temperature than the $\mathrm{Al}_{3} \mathrm{Y}$ phase. In the last step, residual Al crystallizes with other elements in the solid solution and forms a matrix, in which the other phases are embedded. Therefore, the alloys without $\mathrm{Zr}$ can form an amorphous state by terminating the crystallization of the highlymelting $\mathrm{Al}_{3} \mathrm{Zr}$ phase. Moreover, the formation of phases with $\mathrm{Ni}$ and $\mathrm{Fe}$, such as $\mathrm{Al}_{19} \mathrm{Ni}_{5} \mathrm{Y}_{3}, \mathrm{Al}_{10} \mathrm{Fe}_{2} \mathrm{Y}$, and $\mathrm{Al}_{23} \mathrm{Ni}_{6} \mathrm{Y}_{4}$, plays a key role in the formation of amorphous alloys. Atoms in high-entropy alloys cooled at a high rate cannot migrate to form these phases; therefore, an Al-based amorphous phase containing $\mathrm{Fe}, \mathrm{Ni}$, and $\mathrm{Y}$ was formed.

The XPS survey spectrum for the surface of the $\mathrm{Al}_{80} \mathrm{Zr}_{5} \mathrm{Ni}_{5} \mathrm{Fe}_{5} \mathrm{Y}_{5}$ ribbons is presented in Figure 7. The characteristic peaks (O 1s, C 1s, Al 2s, Ni 2p, Y 3d, Y $3 p, \mathrm{Ca} 2 \mathrm{p}, \mathrm{Fe} 2 \mathrm{p}, \mathrm{Y} 3 \mathrm{~s}, \mathrm{Zr} 3 \mathrm{~d}, \mathrm{Al} 2 \mathrm{p}, \mathrm{O} 2 \mathrm{~s}$ ) and Auger spectrum (for O KLL and C KLL) were identified. High intensities relative to the binding energy of oxygen may indicate the formation of a passive layer in the analyzed ribbons. The XPS depth profiles for $\mathrm{Al}_{80} \mathrm{Zr}_{5} \mathrm{Ni}_{5} \mathrm{Fe}_{5} \mathrm{Y}_{5}$ ribbons are shown in Figure 8. As the sputtering time and depth increased, the analyzed material showed a significantly lower $\mathrm{C} 1 \mathrm{~s}$ intensity, which may indicate the presence of carbon from the atmosphere. In the case of $\mathrm{O} 1 \mathrm{~s}$, an increase was observed in the initial part of the test and a decrease after 20 minutes of analysis, which may indicate the presence of oxygen in the passive layers. As the depth of the tested material increased, the 


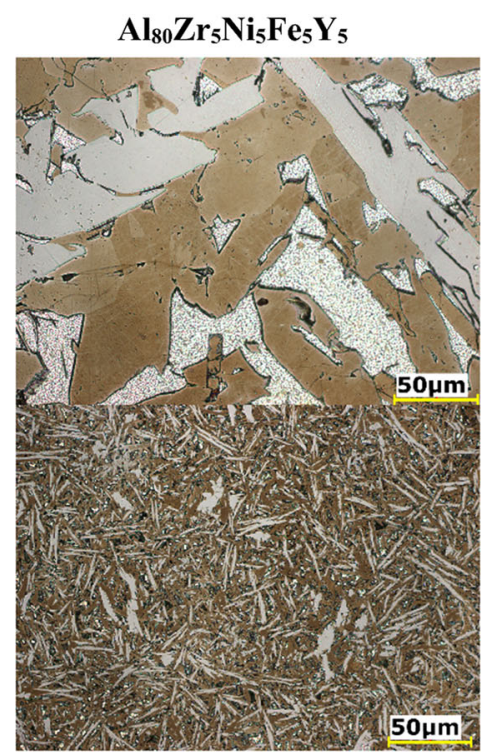

(a)

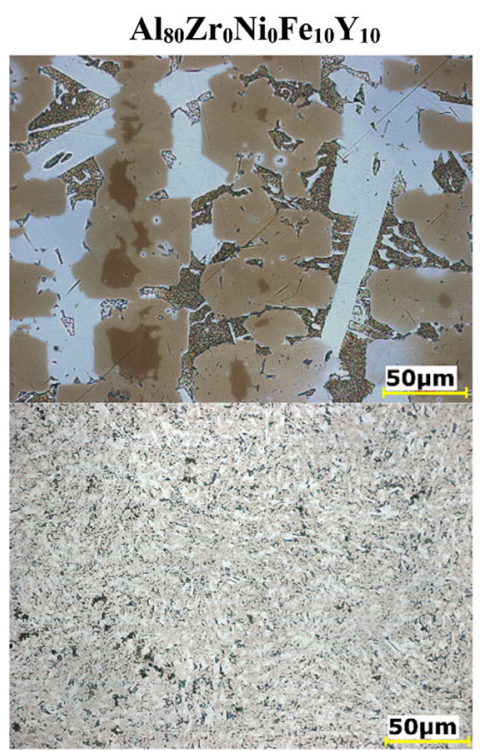

(b)

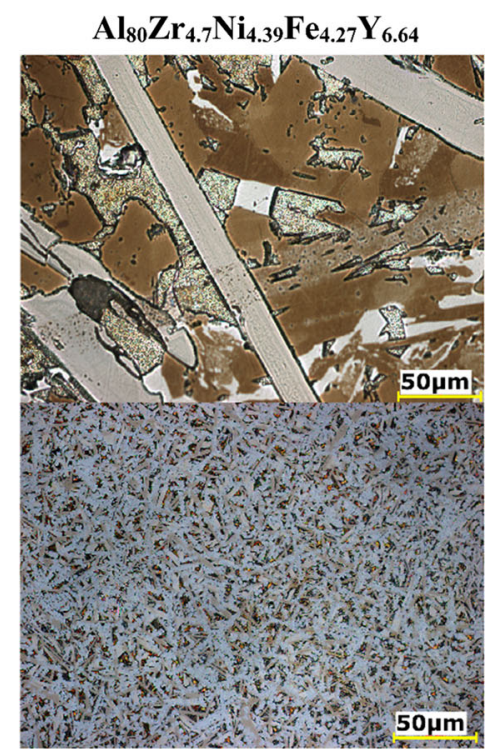

(c)

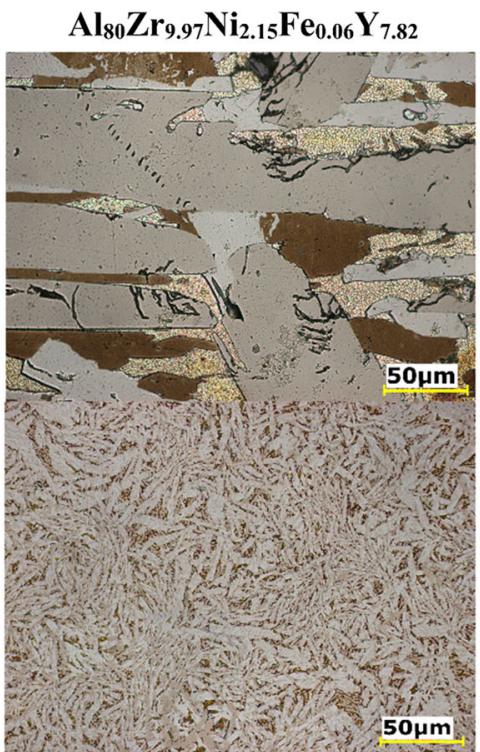

(d)

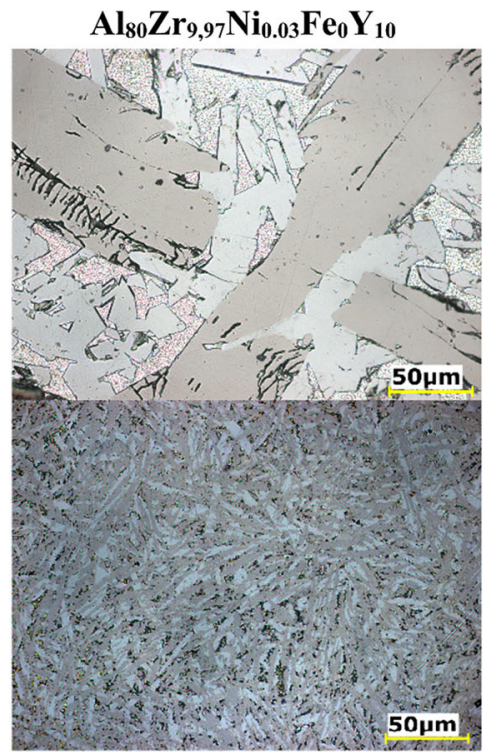

(e)

Fig. 2-Optical microscopy images of all alloys in the as-cast (top image) state and plate form (bottom image); (a) $\mathrm{Al}_{80} \mathrm{Zr}_{5} \mathrm{Ni}_{5} \mathrm{Fe}_{5} \mathrm{Y}_{5},(b)$ $\mathrm{Al}_{80} \mathrm{Zr}_{0} \mathrm{Ni}_{0} \mathrm{Fe}_{10} \mathrm{Y}_{10}$, (c) $\mathrm{Al}_{80} \mathrm{Zr}_{4.7} \mathrm{Ni}_{4.39} \mathrm{Fe}_{4.27} \mathrm{Y}_{6.64}$, (d) $\mathrm{Al}_{80} \mathrm{Zr}_{9.97} \mathrm{Ni}_{2.15} \mathrm{Fe}_{0.06} \mathrm{Y}_{7.82}$, and (e) $\mathrm{Al}_{80} \mathrm{Zr}_{9.97} \mathrm{Ni}_{0.03} \mathrm{Fe}_{0} \mathrm{Y}_{10}$.

Al, Fe, and Ni contents were higher. Figure 9 presents the XPS narrow-scan spectra of Al 2p, Zr 3d, Y 3d, Ni $2 \mathrm{p}, \mathrm{Fe} 2 \mathrm{p}, \mathrm{O} 1 \mathrm{~s}$, and $\mathrm{C} 1 \mathrm{~s}$, respectively. In the obtained spectra, the peak intensity on the surface increased only for $\mathrm{Al} 2 \mathrm{p}, \mathrm{Y} 3 \mathrm{~d}$, and $\mathrm{O} 1 \mathrm{~s}$, and a contaminant $\mathrm{C}$ 1s peak. These results indicate the formation of a passive layer of $\mathrm{Al}_{2} \mathrm{O}_{3}$ and $\mathrm{Y}_{2} \mathrm{O}_{3}$. The literature data ${ }^{[35]}$ concerning $\mathrm{Al}_{2} \mathrm{O}_{3}$ passive layers indicates that diffusion occurs more easily in ribbons than in conventional crystalline alloys. The XPS spectra of $\mathrm{Al}_{80} \mathrm{Zr}_{0} \mathrm{Ni}_{0} \mathrm{Fe}_{10} \mathrm{Y}_{10}$ and $\mathrm{Al}_{80} \mathrm{Zr}_{9.97}$ $\mathrm{Ni}_{2.15} \mathrm{Fe}_{0.06} \mathrm{Y}_{7.82}$ were similar.
Electrochemical studies were used to measure the stationary open-circuit potential as a function of time, and the polarization curves are shown in Figure 10. The results of the open-circuit potential $\left(E_{\mathrm{OCP}}\right)$, corrosion potential $\left(E_{\text {corr }}\right)$, polarization resistance $\left(R_{\mathrm{p}}\right)$, corrosion current density $\left(j_{\text {corr }}\right)$, and corrosion rate $\left(v_{\text {corr }}\right)$ for ingots, plates, and ribbons are listed in Tables V, VI and VII, respectively. The results indicated that changing the cooling rate affected the open-circuit potential and corrosion potential. These values were compared to assess the corrosion resistance between individual alloys 
under the same conditions, which is described in the literature. ${ }^{[36,37]}$ The $E_{\mathrm{OCP}}$ values were the highest for ribbons in all compositions except $\mathrm{Al}_{80} \mathrm{Zr}_{9.97} \mathrm{Ni}_{2.15}$ $\mathrm{Fe}_{0.06} \mathrm{Y}_{7.82}$ and $\mathrm{Al}_{80} \mathrm{Zr}_{9.97} \mathrm{Ni}_{0.03} \mathrm{Fe}_{0} \mathrm{Y}_{10}$, whose plates had more positive values. The polarization curves show that the corrosion potentials $\left(E_{\text {corr }}\right)$ were the highest in the ribbons of all studied alloys. The polarization resistance $\left(R_{\mathrm{p}}\right)$ values were higher for ribbons in compositions: $\quad \mathrm{Al}_{80} \mathrm{Zr}_{5} \mathrm{Ni}_{5} \mathrm{Fe}_{5} \mathrm{Y}_{5} \quad\left(11.1 \quad \mathrm{k} \Omega \mathrm{cm}^{2}\right)$, $\mathrm{Al}_{80} \mathrm{Zr}_{9.97} \mathrm{Ni}_{2.15} \mathrm{Fe}_{0.06} \mathrm{Y}_{7.82}\left(4.8 \mathrm{k} \Omega \mathrm{cm}^{2}\right)$, and $\mathrm{Al}_{85} \mathrm{Ni}_{5}$ $\mathrm{Fe}_{5} \mathrm{Y}_{5}\left(11.2 \mathrm{k} \Omega \mathrm{cm}^{2}\right)$; for ingots: $\mathrm{Al}_{80} \mathrm{Zr}_{0} \mathrm{Ni}_{0} \mathrm{Fe}_{10} \mathrm{Y}_{10}$ (34.6 k $\left.\Omega \mathrm{cm}^{2}\right), \mathrm{Al}_{80} \mathrm{Zr}_{4.7} \mathrm{Ni}_{4.39} \mathrm{Fe}_{4.27} \mathrm{Y}_{6.64}\left(10.2 \mathrm{k} \Omega \mathrm{cm}^{2}\right)$, and $\mathrm{Al}_{80} \mathrm{Zr}_{9.97} \mathrm{Ni}_{0.03} \mathrm{Fe}_{0} \mathrm{Y}_{10}\left(2.4 \mathrm{k} \Omega \mathrm{cm}^{2}\right)$. The corrosion current densities $\left(j_{\text {corr }}\right)$ were the lowest in ribbons: $\mathrm{Al}_{80} \mathrm{Zr}_{5} \mathrm{Ni}_{5} \mathrm{Fe}_{5} \mathrm{Y}_{5} \quad\left(1.58 \quad \mu \mathrm{A} / \mathrm{cm}^{2}\right), \quad \mathrm{Al}_{80} \mathrm{Zr}_{4.7} \mathrm{Ni}_{4.39}$ $\mathrm{Fe}_{4.27} \mathrm{Y}_{6.64}\left(1.99 \mu \mathrm{A} / \mathrm{cm}^{2}\right), \mathrm{Al}_{80} \mathrm{Zr}_{9.97} \mathrm{Ni}_{0.03} \mathrm{Fe}_{0} \mathrm{Y}_{10}$ (4.02 $\left.\mu \mathrm{A} / \mathrm{cm}^{2}\right)$, and $\mathrm{Al}_{85} \mathrm{Ni}_{5} \mathrm{Fe}_{5} \mathrm{Y}_{5}\left(1.08 \mu \mathrm{A} / \mathrm{cm}^{2}\right)$; for ingots: $\mathrm{Al}_{80} \mathrm{Zr}_{0} \mathrm{Ni}_{0} \mathrm{Fe}_{10} \mathrm{Y}_{10}\left(0.45 \mu \mathrm{A} / \mathrm{cm}^{2}\right)$ and $\mathrm{Al}_{80} \mathrm{Zr}_{9.97} \mathrm{Ni}_{2.15}$ $\mathrm{Fe}_{0.06} \mathrm{Y}_{7.82}\left(2.12 \mu \mathrm{A} / \mathrm{cm}^{2}\right)$. The effect of the cooling rate between plates and ribbons was also determined based on the calculated corrosion rates. $\mathrm{Al}_{80} \mathrm{Zr}_{5} \mathrm{Ni}_{5} \mathrm{Fe}_{5} \mathrm{Y}_{5}$, $\mathrm{Al}_{80} \mathrm{Zr}_{9.97} \mathrm{Ni}_{2.15} \mathrm{Fe}_{0.06} \mathrm{Y}_{7.82}, \mathrm{Al}_{80} \mathrm{Zr}_{9.97} \mathrm{Ni}_{0.03} \mathrm{Fe}_{0} \mathrm{Y}_{10}$, and $\mathrm{Al}_{85} \mathrm{Ni}_{5} \mathrm{Fe}_{5} \mathrm{Y}_{5}$ showed lower $v_{\text {corr }}$ values, which was related to their higher corrosion resistance. Figure 11 presents the surface morphology of plates after electrochemical tests. The effect of galvanic microcells was observed due to the presence of multiple phases and structural defects in the crystalline structure. The brighter and darker areas indicated the activity of individual phases with corrosion potentials that are different than Al. According to the electrochemical tests,

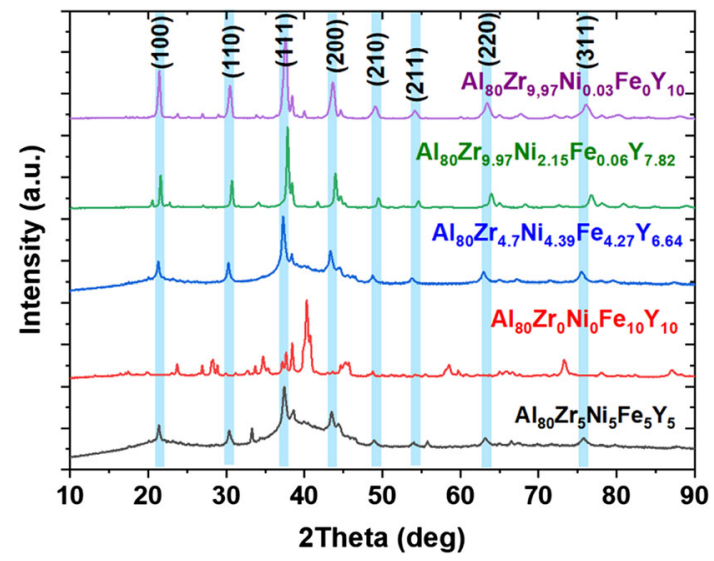

Fig. 3-XRD patterns of alloys in the form of ribbons with $\mathrm{Al}_{3} \mathrm{Zr}$ phase marked. the greatest surface damage as indicated by the highest $v_{\text {corr }}$ values was observed for $\mathrm{Al}_{80} \mathrm{Zr}_{9.97} \mathrm{Ni}_{2.15} \mathrm{Fe}_{0.06} \mathrm{Y}_{7.82}$ and $\mathrm{Al}_{80} \mathrm{Zr}_{9.97} \mathrm{Ni}_{0.03} \mathrm{Fe}_{0} \mathrm{Y}_{10}$ plates.

The highest corrosion resistance, including a low corrosion current density and polarization resistance, was observed for ribbons of $\mathrm{Al}_{80} \mathrm{Zr}_{5} \mathrm{Ni}_{5} \mathrm{Fe}_{5} \mathrm{Y}_{5}$ and $\mathrm{Al}_{85} \mathrm{Ni}_{5} \mathrm{Fe}_{5} \mathrm{Y}_{5}$. The literature data ${ }^{[38]}$ highlights the possibility of improving the corrosion resistance of magnesium alloys (i.e., $\mathrm{Mg}-\mathrm{Nd}$ and $\mathrm{Mg}-\mathrm{Y}$ alloys) by using rapid solidification processes. Moreover, Das and Davis $^{[39]}$ indicated the influence of rapid solidification

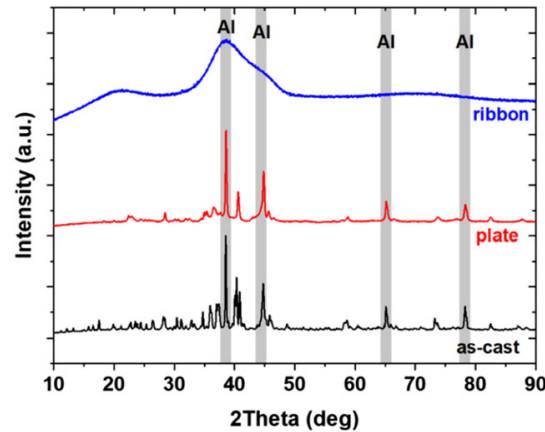

(a)

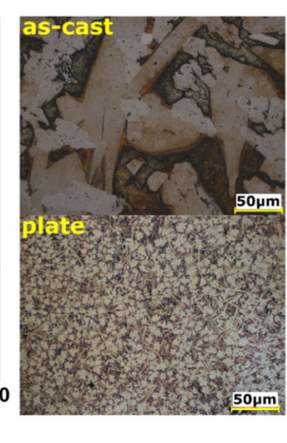

(b)
Fig. 4 - (a) XRD patterns of $\mathrm{Al}_{85} \mathrm{Ni}_{5} \mathrm{Fe}_{5} \mathrm{Y}_{5}$ alloy in the as-cast state, in the form of plates and ribbons; $(b)$ optical microscopy images recorded for the as-cast alloy (top) and in plate form (bottom).

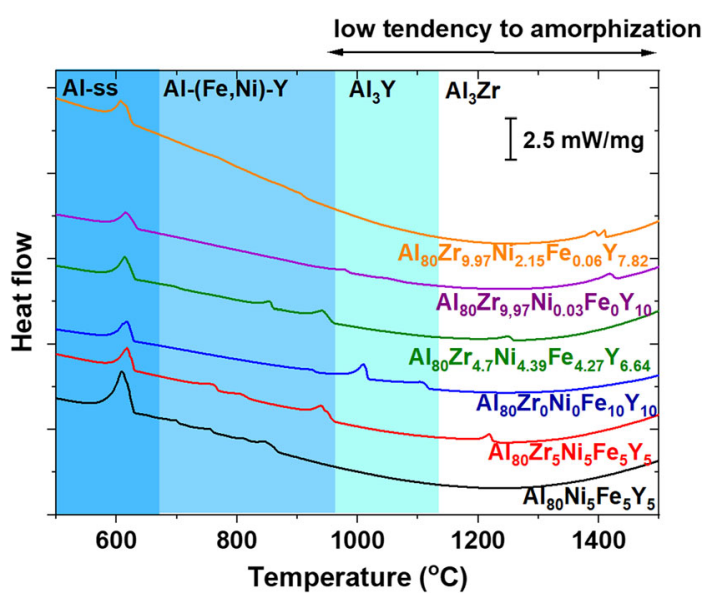

Fig. 5-DTA cooling curves recorded for all alloys in the as-cast state with the marked temperature ranges corresponding to the crystallization of phases identified in the XRD patterns (Al-ss = aluminum solid solution).

Table IV. Phases Identified for Alloys in the Form of Ribbons (the Main Phases are in Bold)

\begin{tabular}{lll}
\hline Optimized Parameter & \multicolumn{1}{c}{ Chemical Composition } & \multicolumn{1}{c}{ Identified Phases } \\
\hline$\Delta S^{\text {config }}$ & $\mathrm{Al}_{80} \mathrm{Zr}_{5} \mathrm{Ni}_{5} \mathrm{Fe}_{5} \mathrm{Y}_{5}$ & $\mathrm{Amorphous}+\mathrm{Al}_{3} \mathrm{Zr}+\mathrm{Al}+\mathrm{AlNi}_{2} \mathrm{Y}_{2}$ \\
$\Delta S^{\text {mis }}$ & $\mathrm{Al}_{80} \mathrm{Zr}_{0} \mathrm{Ni}_{0} \mathrm{Fe}_{10} \mathrm{Y}_{10}$ & $\mathrm{Al}_{10} \mathrm{Fe}_{2} \mathrm{Y}+\mathrm{Al}+\mathrm{Al}_{3} \mathrm{Y}$ \\
$\Delta S^{\text {sum }}$ & $\mathrm{Al}_{80} \mathrm{Zr}_{4.7} \mathrm{Ni}_{4.39} \mathrm{Fe}_{4.27} \mathrm{Y}_{6.64}$ & $\mathrm{Amorphous} \mathrm{Al}_{3} \mathrm{Zr}+\mathrm{Al}_{+} \mathrm{Fe}_{0.7} \mathrm{Ni}_{1.3} \mathrm{Al}_{9}$ \\
$\Delta G^{\text {mix, conf }}$ & $\mathrm{Al}_{80} \mathrm{Zr}_{9.97} \mathrm{Ni}_{2.15} \mathrm{Fe}_{0.06} \mathrm{Y}_{7.82}$ & $\mathrm{Al}_{3} \mathrm{Zr}+\mathrm{Al} \mathrm{Zr}_{3}+\mathrm{Al}$ \\
$\Delta G^{\text {mix, mis }}$ & $\mathrm{Al}_{80} \mathrm{Zr}_{9.97} \mathrm{Ni}_{0.03} \mathrm{Fe}_{0} \mathrm{Y}_{10}$ & $\mathrm{Al}_{3} \mathrm{Zr}+\mathrm{Al}{ }_{3} \mathrm{Y}+\mathrm{Al}$ \\
\hline
\end{tabular}



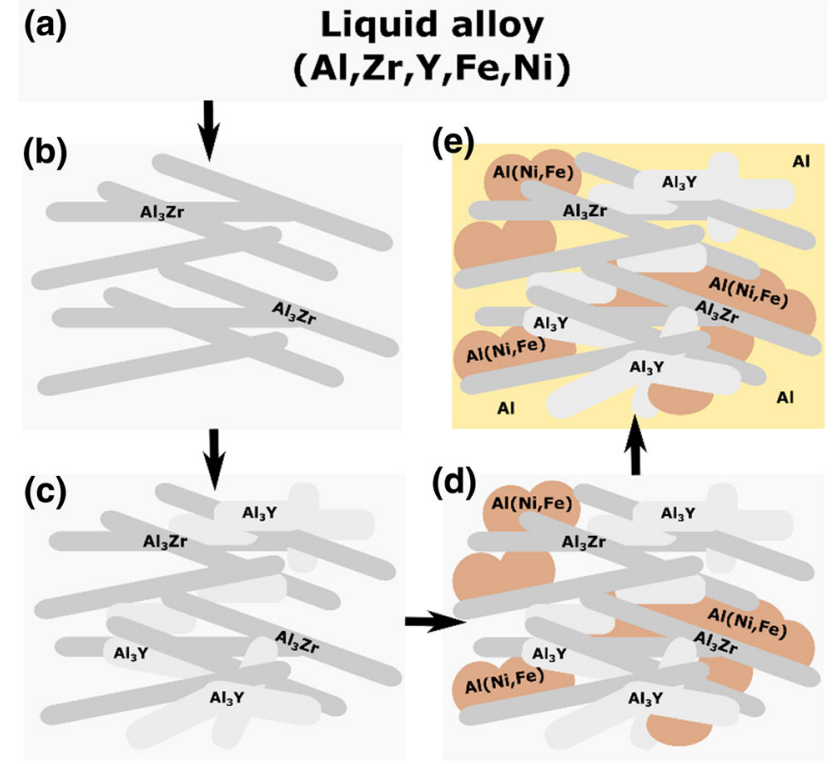

Fig. 6-Schematic representation of the crystallization process of Al-Zr-Ni-Fe-Y alloys: $(a)$ melted alloy, $(b) \mathrm{Al}_{3} \mathrm{Zr}$ phase crystallized from the liquid state, $(c) \mathrm{Al}_{3} \mathrm{Y}$ phase crystallized on the surface of $\mathrm{Al}_{3} \mathrm{Zr}$ phase, (d) formation of $\mathrm{Al}(\mathrm{Ni}, \mathrm{Fe})$ phases, $(e)$ crystallization of residual $\mathrm{Al}$

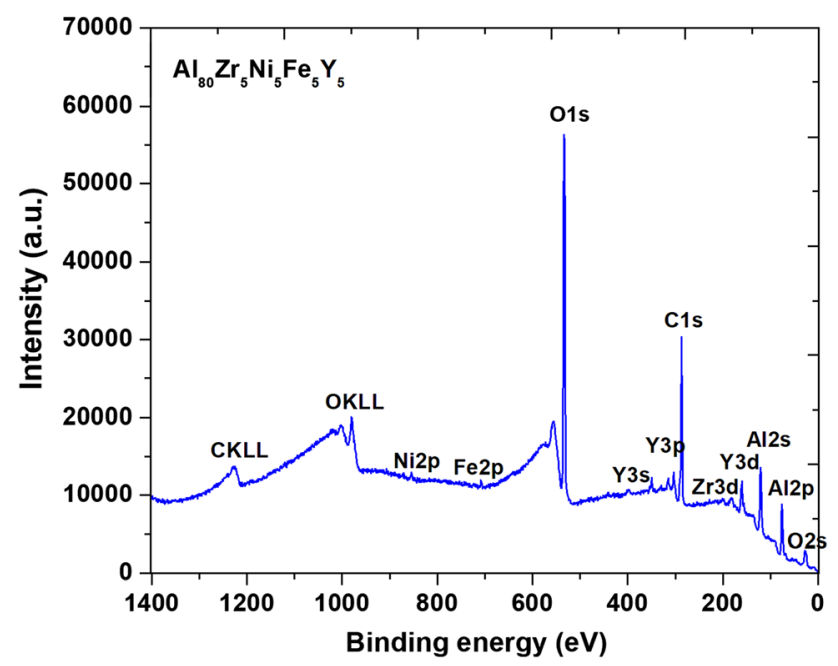

Fig. 7-XPS survey spectrum of the surface of $\mathrm{Al}_{80} \mathrm{Zr}_{5} \mathrm{Ni}_{5} \mathrm{Fe}_{5} \mathrm{Y}_{5}$ ribbon.

on the corrosion resistance of Al-TM. Homogenization of the structure has been shown to prevent the formation of galvanic microcells and create protective surface layers in a fully amorphous $\mathrm{Al}_{85} \mathrm{Ni}_{5} \mathrm{Fe}_{5} \mathrm{Y}_{5}$ alloy. ${ }^{[40]}$

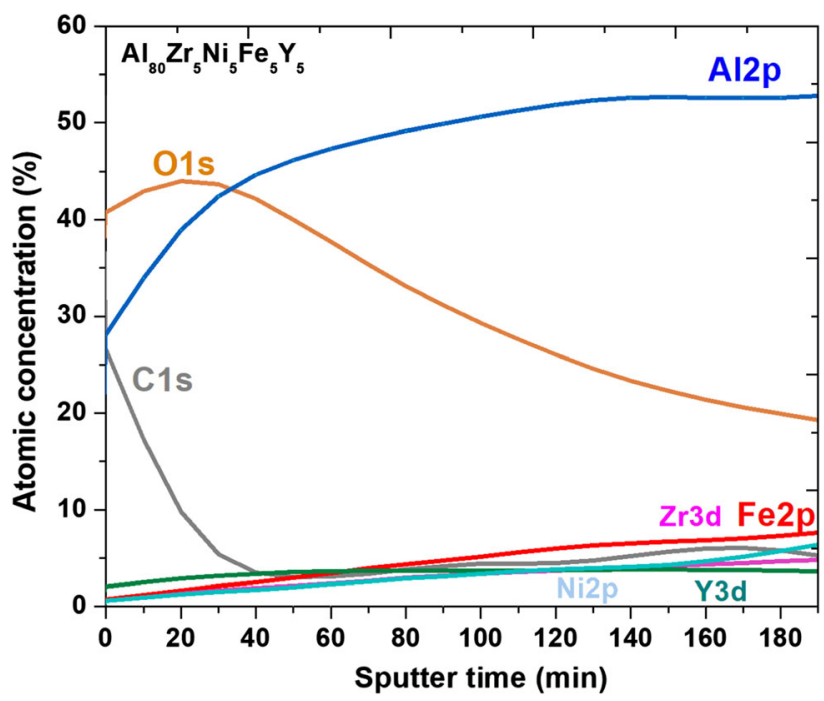

Fig. 8-XPS depth profiles of $\mathrm{Al}_{80} \mathrm{Zr}_{5} \mathrm{Ni}_{5} \mathrm{Fe}_{5} \mathrm{Y}_{5}$ ribbon.

However, for $\mathrm{Al}_{80} \mathrm{Zr}_{5} \mathrm{Ni}_{5} \mathrm{Fe}_{5} \mathrm{Y}_{5}$, which contained additional crystalline phases, the lower corrosion rate due to thermodynamic stability was achieved due to partial crystallization. ${ }^{[11,42]}$

\section{CONCLUSIONS}

In this study, we investigated the possibility of using a thermodynamic approach to determine the chemical composition of Al-based alloys containing $\mathrm{Zr}$, Fe, Ni, and $Y$. The results confirmed that the optimization of different entropic parameters could be used to describe the crystallization mechanism as well as the glass-forming ability of these alloys. It was concluded that the addition of zirconium negatively impacted the GFA, which was related to the formation of the $\mathrm{Al}_{3} \mathrm{Zr}$ phase. The results also indicated the formation of an amorphous phase in Al-based alloys containing transition metals such as $\mathrm{Fe}, \mathrm{Ni}$, and $\mathrm{Y}$ due to their high entropy in the liquid state. The high entropy prevented the crystallization of $\mathrm{Al}_{19} \mathrm{Ni}_{5} \mathrm{Y}_{3}, \mathrm{Al}_{10} \mathrm{Fe}_{2} \mathrm{Y}$, and $\mathrm{Al}_{23} \mathrm{Ni}_{6} \mathrm{Y}_{4}$ phases, which manifested in the formation of a metastable amorphous structure. XPS analysis showed a tendency to form a passive layer of $\mathrm{Al}_{2} \mathrm{O}_{3}$ and $\mathrm{Y}_{2} \mathrm{O}_{3}$ that confirmed an easier passivation process for ribbons. The electrochemical tests revealed that the high cooling rate shifted the open-circuit potential and corrosion potential to more positive values. The best compositions from a corrosion resistance perspective were $\mathrm{Al}_{80} \mathrm{Zr}_{5}$ $\mathrm{Ni}_{5} \mathrm{Fe}_{5} \mathrm{Y}_{5}$ and $\mathrm{Al}_{85} \mathrm{Ni}_{5} \mathrm{Fe}_{5} \mathrm{Y}_{5}$ ribbons. The 

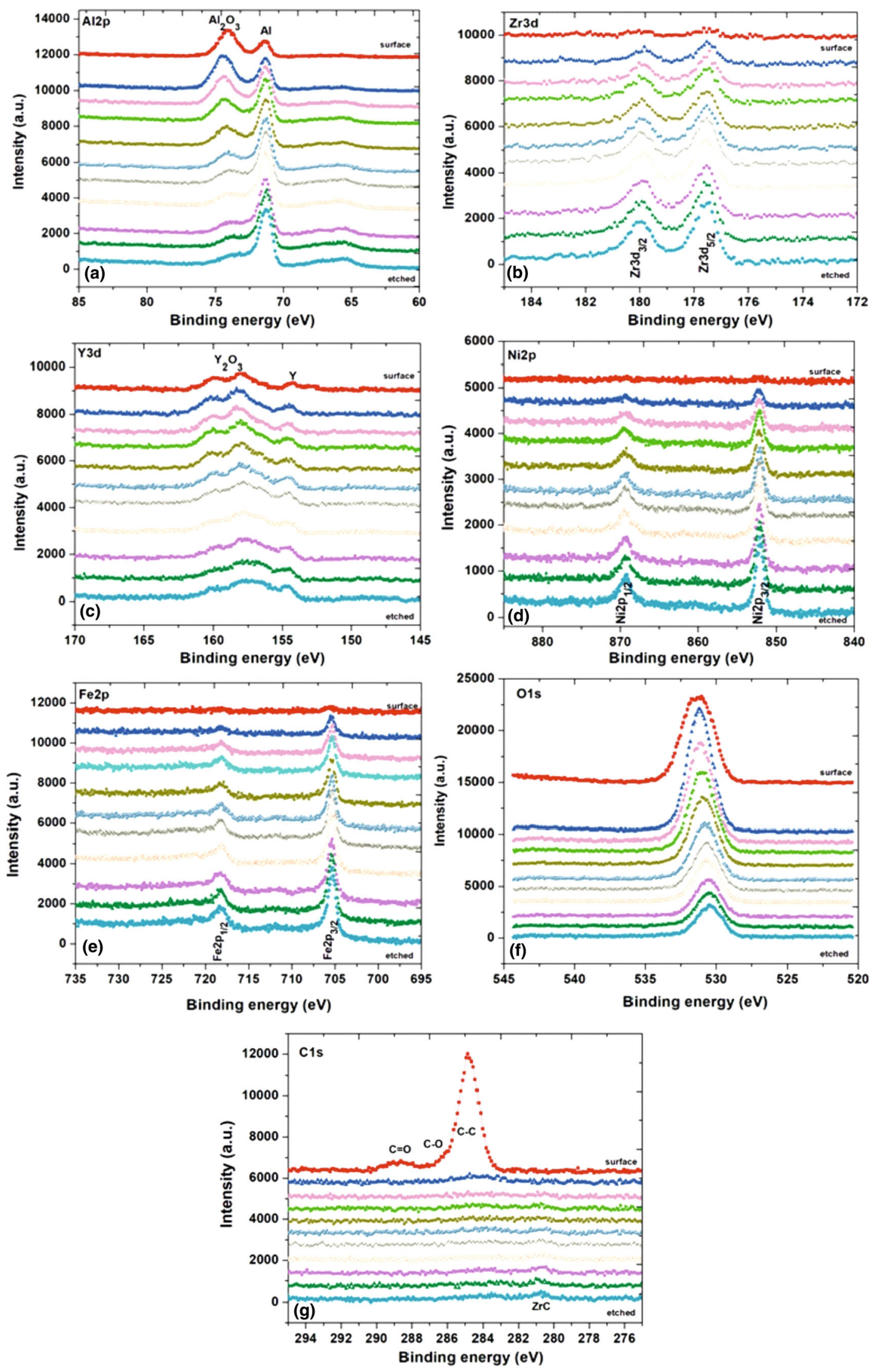

Fig. 9-XPS narrow-scan spectra of Al2p (a), Zr3d (b), Y3d (c), Ni2p (d), Fe2p (e), O1s (f), and C1s (g). 

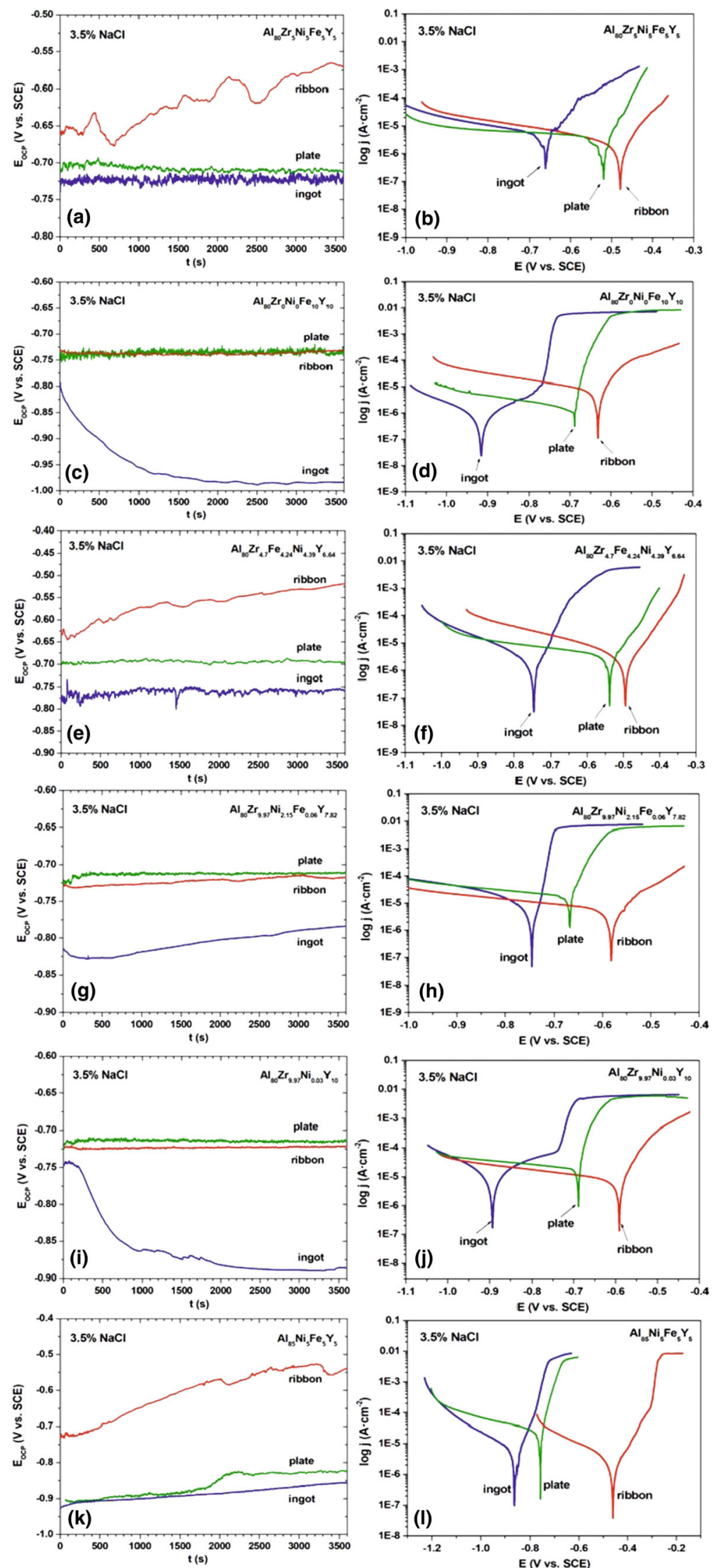

Fig. 10-Variation of the open-circuit potential with time $(a, c, e, g, i, k)$ and polarization curves $(b, d, f, h, j, l)$ in the as-cast state, in the form of ribbons and plates in 3.5 pet $\mathrm{NaCl}$ solution at $25^{\circ} \mathrm{C}$. 
Table V. Polarization Tests of As-Cast State Ingots in 3.5 Pct NaCl Solution

\begin{tabular}{lccccc}
\hline As-cast state & $\begin{array}{c}E_{\mathrm{OCP}}[\mathrm{V}]( \pm \\
0.01)\end{array}$ & $\begin{array}{c}E_{\text {corr }}[\mathrm{V}]( \pm \\
0.01)\end{array}$ & $\begin{array}{c}R_{\mathrm{p}}\left[\mathrm{k} \Omega \mathrm{cm}^{2}\right]( \pm \\
0.1)\end{array}$ & $\begin{array}{c}j_{\text {corr }}\left[\mu \mathrm{A} / \mathrm{cm}^{2}\right]( \pm \\
0.1)\end{array}$ & $\begin{array}{c}v_{\text {corr }}[\mathrm{mm} / \text { year }] \\
( \pm 0.01)\end{array}$ \\
\hline $\mathrm{Al}_{80} \mathrm{Zr}_{5} \mathrm{Ni}_{5} \mathrm{Fe}_{5} \mathrm{Y}_{5}$ & -0.718 & -0.660 & 3.3 & 3.22 & 0.11 \\
$\mathrm{Al}_{80} \mathrm{Zr}_{0} \mathrm{Ni}_{0} \mathrm{Fe}_{10} \mathrm{Y}_{10}$ & -0.984 & -0.915 & 34.6 & 0.45 & 0.02 \\
$\mathrm{Al}_{80} \mathrm{Zr}_{4.7} \mathrm{Ni}_{4.39} \mathrm{Fe}_{4.27} \mathrm{Y}_{6.64}$ & -0.758 & -0.749 & 10.2 & 4.78 & 0.16 \\
$\mathrm{Al}_{80} \mathrm{Zr}_{9.97} \mathrm{Ni}_{2.15} \mathrm{Fe}_{0.06} \mathrm{Y}_{7.82}$ & -0.784 & -0.745 & 3.0 & 2.12 & 0.08 \\
$\mathrm{Al}_{80} \mathrm{Zr}_{9.97} \mathrm{Ni}_{0.03} \mathrm{Fe}_{0} \mathrm{Y}_{10}$ & -0.886 & -0.894 & 2.4 & 1.63 & 0.25 \\
$\mathrm{Al}_{85} \mathrm{Ni}_{5} \mathrm{Fe}_{5} \mathrm{Y}_{5}$ & -0.855 & -0.857 & 4.6 & 0.05 \\
\hline
\end{tabular}

Table VI. Polarization Tests of Plates in 3.5 Pct NaCl Solution

\begin{tabular}{|c|c|c|c|c|c|}
\hline Plates & $\begin{array}{c}E_{\mathrm{OCP}}[\mathrm{V}]( \pm \\
0.01)\end{array}$ & $\begin{array}{c}E_{\text {corr }}[\mathrm{V}]( \pm \\
0.01)\end{array}$ & $R_{\mathrm{p}}\left[\mathrm{k} \Omega \mathrm{cm}^{2}\right]( \pm$ & $\begin{array}{c}j_{\text {corr }}\left[\mu \mathrm{A} / \mathrm{cm}^{2}\right]( \pm \\
0.1)\end{array}$ & $v_{\text {corr }}[\mathrm{mm} /$ year $]( \pm$ \\
\hline $\mathrm{Al}_{80} \mathrm{Zr}_{5} \mathrm{Ni}_{5} \mathrm{Fe}_{5} \mathrm{Y}_{5}$ & -0.711 & -0.519 & 6.3 & 2.27 & 0.08 \\
\hline $\mathrm{Al}_{80} \mathrm{Zr}_{0} \mathrm{Ni}_{0} \mathrm{Fe}_{10} \mathrm{Y}_{10}$ & -0.738 & -0.688 & 3.1 & 1.24 & 0.04 \\
\hline $\mathrm{Al}_{80} \mathrm{Zr}_{4.7} \mathrm{Ni}_{4.39} \mathrm{Fe}_{4.27} \mathrm{Y}_{6.64}$ & -0.694 & -0.537 & 4.9 & 2.11 & 0.07 \\
\hline $\mathrm{Al}_{80} \mathrm{Zr}_{9.97} \mathrm{Ni}_{2.15} \mathrm{Fe}_{0.06} \mathrm{Y}_{7.82}$ & -0.714 & -0.668 & 0.4 & 6.61 & 0.24 \\
\hline $\mathrm{Al}_{80} \mathrm{Zr}_{9.97} \mathrm{Ni}_{0.03} \mathrm{Fe}_{0} \mathrm{Y}_{10}$ & -0.713 & -0.688 & 0.4 & 8.83 & 0.33 \\
\hline $\mathrm{Al}_{85} \mathrm{Ni}_{5} \mathrm{Fe}_{5} \mathrm{Y}_{5}$ & -0.819 & -0.759 & 0.6 & 3.46 & 0.11 \\
\hline
\end{tabular}

Table VII. Polarization Tests of Ribbons in 3.5 Pct NaCl Solution

\begin{tabular}{lccccc}
\hline Ribbons & $E_{\mathrm{OCP}}[\mathrm{V}]( \pm$ & $E_{\text {corr }}[\mathrm{V}]( \pm$ & $R_{p}\left[\mathrm{k} \Omega \mathrm{cm}^{2}\right]( \pm$ & $j_{\text {corr }}\left[\mu \mathrm{A} / \mathrm{cm}^{2}\right]( \pm$ & $0.1)$ \\
\hline & $0.01)$ & $0.01)$ & $0.1)$ & 1.58 & $0.01)$ \\
$\mathrm{Al}_{80} \mathrm{Zr}_{5} \mathrm{Ni}_{5} \mathrm{Fe}_{5} \mathrm{Y}_{5}$ & -0.571 & -0.478 & 11.1 & 3.51 & 0.05 \\
$\mathrm{Al}_{80} \mathrm{Zr}_{0} \mathrm{Ni}_{0} \mathrm{Fe}_{10} \mathrm{Y}_{10}$ & -0.731 & -0.632 & 3.1 & 1.99 & 0.12 \\
$\mathrm{Al}_{80} \mathrm{Zr}_{4.7} \mathrm{Ni}_{4.39} \mathrm{Fe}_{4.27} \mathrm{Y}_{6.64}$ & -0.519 & -0.495 & 9.3 & 2.61 & 0.07 \\
$\mathrm{Al}_{80} \mathrm{Zr}_{9.97} \mathrm{Ni}_{2.15} \mathrm{Fe}_{0.06} \mathrm{Y}_{7.82}$ & -0.717 & -0.582 & 4.8 & 4.02 & 0.09 \\
$\mathrm{Al}_{80} \mathrm{Zr}_{9.97} \mathrm{Ni}_{0.03} \mathrm{Fe}_{0} \mathrm{Y}_{10}$ & -0.721 & -0.598 & 1.4 & 1.08 & 0.15 \\
$\mathrm{Al}_{85} \mathrm{Ni}_{5} \mathrm{Fe}_{5} \mathrm{Y}_{5}$ & -0.538 & -0.461 & 11.2 & 0.04 \\
\hline
\end{tabular}

homogenization of the structure, which prevented the formation of galvanic microcells, was observed in amorphous $\mathrm{Al}_{85} \mathrm{Ni}_{5} \mathrm{Fe}_{5} \mathrm{Y}_{5}$. Moreover, the reduction in the corrosion rate due to thermodynamic stability was also achieved in $\mathrm{Al}_{80} \mathrm{Zr}_{5} \mathrm{Ni}_{5} \mathrm{Fe}_{5} \mathrm{Y}_{5}$, in which $\mathrm{Al}_{3} \mathrm{Zr}$ nanocrystallites were embedded in the amorphous matrix. 


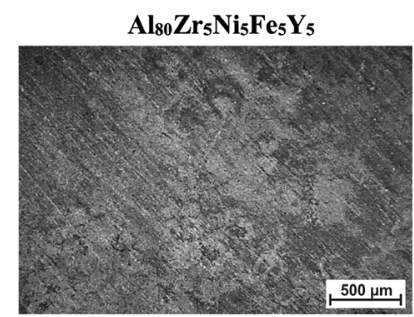

(a)

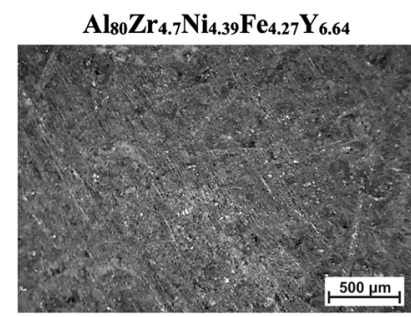

(c)

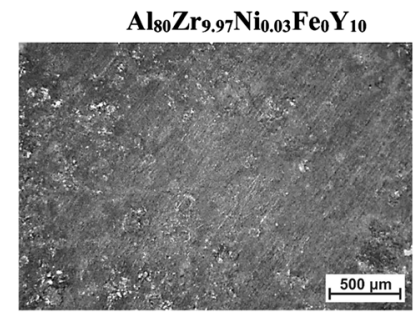

(e)

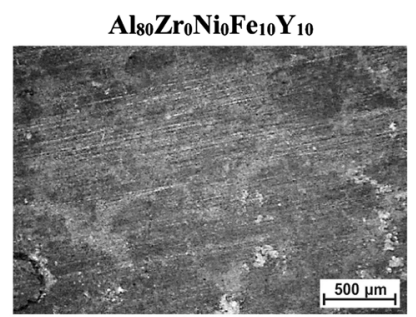

(b)

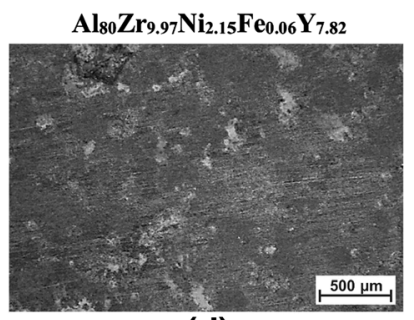

(d)

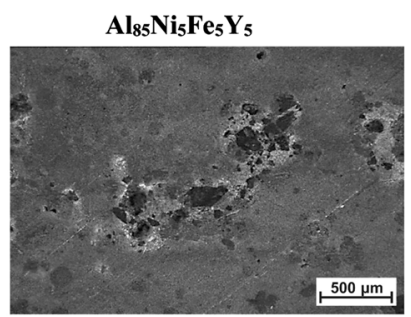

(f)
Fig. 11-Surface morphology of (a) $\quad \mathrm{Al}_{80} \mathrm{Zr}_{5} \mathrm{Ni}_{5} \mathrm{Fe}_{5} \mathrm{Y}_{5}, \quad$ (b) $\mathrm{Al}_{80} \mathrm{Zr}_{0} \mathrm{Ni}_{0} \mathrm{Fe}_{10} \mathrm{Y}_{10}, \quad$ (c) $\quad \mathrm{Al}_{80} \mathrm{Zr}_{4.7} \mathrm{Ni}_{4.39} \mathrm{Fe}_{4.27} \mathrm{Y}_{6.64}, \quad$ (d) $\mathrm{Al}_{80} \mathrm{Zr}_{9.97} \mathrm{Ni}_{2.15} \mathrm{Fe}_{0.06} \mathrm{Y}_{7.82}$, (e) $\mathrm{Al}_{80} \mathrm{Zr}_{9.97} \mathrm{Ni}_{0.03} \mathrm{Fe}_{0} \mathrm{Y}_{10}$, and $(f)$ $\mathrm{Al}_{85} \mathrm{Ni}_{5} \mathrm{Fe}_{5} \mathrm{Y}_{5}$ alloys in the form of plates after polarization tests in 3.5 pet $\mathrm{NaCl}$ solution at $25{ }^{\circ} \mathrm{C}$.

\section{FUNDING}

The work was supported by the National Science Centre of Poland under research Project No. 2018/29/ $\mathrm{B} / \mathrm{ST} 8 / 02264$.

\section{OPEN ACCESS}

This article is licensed under a Creative Commons Attribution 4.0 International License, which permits use, sharing, adaptation, distribution and reproduction in any medium or format, as long as you give appropriate credit to the original author(s) and the source, provide a link to the Creative Commons licence, and indicate if changes were made. The images or other third party material in this article are included in the article's Creative Commons licence, unless indicated otherwise in a credit line to the material. If material is not included in the article's Creative Commons licence and your intended use is not permitted by statutory regulation or exceeds the permitted use, you will need to obtain permission directly from the copyright holder. To view a copy of this licence, visit http://creat ivecommons.org/licenses/by/4.0/.

\section{REFERENCES}

1. A. Inoue and H. Kimura: J. Light Met., 2001, vol. 1, pp. 31-41.

2. E.J. Lavernia, J.D. Ayers, and T.S. Srivatsan: Int. Mater. Rev., 1992, vol. 37, pp. 1-44.

3. Y. He, G.J. Shiflet, and S.J. Poon: J. Alloys Compd., 1994, vols. 207-208, pp. 349-54.

4. M.S. El-Eskandarany: Mech. Alloy., 2015, pp. 1-12.

5. A. Inoue: Acta Mater., 2000, vol. 48, pp. 279-306.

6. X.F. Bian, B.A. Sun, L.N. Hu, and Y.B. Jia: Phys. Lett. A., 2005, vol. 335 , pp. 61-7.

7. F.Q. Guo, S.J. Poon, and G.J. Shiflet: Mater. Sci. Forum., 2000, vols. 331-337, pp. 31-42.

8. S.J. Poon, G.J. Shiflet, F.Q. Guo, and V. Ponnambalam: J. Non Cryst. Solids., 2003, vol. 317, pp. 1-9.

9. K. Saksl, P. Jóvári, H. Franz, and J.Z. Jiang: J. Appl. Phys., 2005, vol. 97 , pp. 1-8.

10. M. Blank-Bewersdorff: J. Mater. Sci. Lett., 1991, vol. 10, pp. $1225-7$

11. Q. Li, E. Johnson, M.B. Madsen, A. Johansen and L. Sarholt-Kristensen: Philos. Mag. B Phys. Condens. Matter; Stat. Mech. Electron. Opt. Magn. Prop., 1992, vol. 66, pp. 427-42.

12. M.C. Gao, R.E. Hackenberg, and G.J. Shiflet: Mater. Trans., 2001, vol. 42, pp. 1741-47.

13. Y.H. Kim, A. Inoue, and T. Masumoto: Mater. Trans. JIM., 1991, vol. 32 , pp. $331-8$.

14. A. Inoue, Y. Horio, and T. Masumoto: Mater. Trans. JIM., 1993, vol. 34 , pp. $85-88$.

15. X.Y. Jiang, Z.C. Zhong, and A.L. Greer: Mater. Sci. Eng. A., 1997, vols. 226-228, pp. 789-93.

16. Y. He, G.M. Dougherty, G.J. Shiflet, and S.J. Poon: Acta Metall. Mater., 1993, vol. 41, pp. 337-43.

17. M. Yan, J.Q. Wang, C. Kong, G.B. Schaffer, and M. Qian: $J$. Mater. Res., 2012, vol. 27, pp. 2131-9.

18. P.P. Choi, J.S. Kim, O.T.H. Nguyen, D.H. Kwon, Y.S. Kwon, and J.C. Kim: Mater. Sci. Eng. A., 2007, vols. 449-451, pp. 1119-22.

19. P. Rizzi, M. Baricco, S. Borace, and L. Battezzati: Mater. Sci. Eng. A., 2001, vols. 304-306, pp. 574-8.

20. R.S. Rana, R. Purohit, and S. Das: Int. J. Sci. Res. Publ., 2012, vol. 2, pp. 1-7.

21. Y. Deng, Z. Yin, K. Zhao, J. Duan, J. Hu, and Z. He: Corros. Sci., 2012 , vol. 65 , pp. $288-98$.

22. T.T. Sasaki, T. Ohkubo and: K. Hono: Acta Mater., 2009, vol. 57, pp. 3529-38

23. Y. Shen and J.H. Perepezko: J. Alloys Compd., 2017, vol. 707, pp. 3-11.

24. A.A. Deshmukh, A.A. Khond, and U.A. Palikundwar: J. Non. Cryst. Solids., 2017, vol. 407, pp. 50-57.

25. A. Takeuchi, N. Chen, T. Wada, W. Zhang, Y. Yokoyama, A. Inoue, and J.W. Yeh: Procedia Eng., 2012, vol. 36, pp. 226-34.

26. J. Huo, L. Huo, J. Li, H. Men, X. Wang, A. Inoue, C. Chang, J.Q. Wang, and R.W. Li: J. Appl. Phys., 2015, vol. 117, pp. 1-5.

27. T. Qi, Y. Li, A. Takeuchi, G. Xie, H. Miao, and W. Zhang: Intermetallics, 2015, vol. 66, pp. 8-12.

28. Y.F. Ye, Q. Wang, J. Lu, C.T. Liu, and Y. Yang: Mater. Today., 2016, vol. 19, pp. 349-62.

29. A. Takeuchi and A. Inoue: Mater. Trans. Jim., 2000, vol. 41, pp. $1372-78$.

30. F.R. de Boer, R. Boom, W.C.M. Mattens, A.R. Miedema and A.K. Niessen: Cohesion and structure,1st ed., North-Holland, Amsterdam, 1989.

31. R.F. Zhang, S.H. Sheng, and B.X. Liu: Chem. Phys. Lett., 2007, vol. 442 , pp. 511-14.

32. H. Bakker: Trans. Tech. Publ., 1998, vol. 1, pp. 96-104.

33. R.F. Zhang and K. Rajan: Chem. Phys. Lett., 2014, vol. 612, pp. $177-81$.

34. E. McCafferty: Corros. Sci., 2005, vol. 47, pp. 3202-15.

35. J.A. Shi, C.R. Cao, Q.H. Zhang, Y.T. Sun, C. Wang, W.H. Wang, H.Y. Bai, and L. Gu: Scr. Mater., 2017, vol. 136, pp. 68-73.

36. S. Kirtay: Acta Phys. Pol. A., 2015, vol. 128, pp. 90-2.

37. J. Pi, Y. Pan, J. Wu, and X. He: Met. Mater. Eng., 2014, vol. 43, pp. 32-35. 
38. S. Krishnamurthy, M. Khobaib, E. Robertson, and F.H. Froes: Mater. Sci. Eng., 1988, vol. 99, pp. 507-11.

39. S.K. Das and L.A. Davis: Mater. Sci. Eng., 1988, vol. 98, pp. 1-12.

40. F. Hermann, F. Sommer, H. Jones, and R.G.J. Edyvean: J. Mater. Sci., 1989, vol. 24, pp. 2369-79.

41. J.G. Lin, W.W. Wang, X.Q. Wu, J.H. Lei, and S. Yin: J. Alloys Compd., 2009, vol. 478, pp. 763-66.
42. Y. Wang, M.J. Tan, J. Pang, Z. Wang, and A.W.E. Jarfors: Mater. Chem. Phys., 2012, vol. 134, pp. 1079-87.

Publisher's Note Springer Nature remains neutral with regard to jurisdictional claims in published maps and institutional affiliations. 